\title{
Role Conflict, Role Ambiguity and Nurses' Performance at Minia University Hospital
}

\author{
Eman A. Abd Elhamid, Fatma R .Mohamed \& Sahar A. Abood \\ Clinical demonstrator in nursing Administration Department Faculty of Nursing Minia University \\ Assistant professor of Nursing Administration Faculty of Nursing Assiut University \\ Assistant professor of Nursing Administration Faculty of Nursing Minia University
}

\begin{abstract}
:
Background: Role conflict and role ambiguity frequently emerge as problems that result from the demands of organization and can be components of role stress and role strain. Professional healthcare providers must clearly understand what is expected of their performance, this can be achieved when all member in the organization have clearly defined roles and overall objectives .Aim:1- Identify causes of role conflict and role ambiguity at Minia University Hospital. 2- Determine level of role conflict, role ambiguity and nurses' performance at Minia University, and 3- To find out the relation among role conflict, role ambiguity and nurses' performance at Minia University Hospital. Research design: The study was developed within a descriptive correlational approach. Setting: The study carried out at Minia University Hospital .Subjects: a total of 85 nurses who worked in all general and special inpatient units at Minia University Hospital. Tools of data collection: The study tools consisted of three tools, it includes1-Personal data sheet 2- Role conflict and role ambiguity questionnaire, 3) Observation checklist for Assessment of Nursing Performance. Results: the performance of the studied nurses have negative correlation with role conflict $(r=-0.183 \& \mathrm{p}=0.094)$ and with role ambiguity $(\mathrm{r}=-0.119 \& \mathrm{p}=0.279)$. There is a positive correlation between role ambiguity and role conflict $(\mathrm{r}=0.5 \& \mathrm{p}=0.0000)$. Conclusion: our study concluded that majority of studied sample at Minia University Hospital have high level of role conflict and role ambiguity regardless of demographic characteristics. Recommendations: On the light of the study, it was recommended that: Nursing managers should plan an orientation program to orient nurses about hospital policy, rules, regulation, job description and responsibilities, other's expectation, facilities, equipment, and performance evaluation standard.
\end{abstract}

\section{Keywords: Role conflict- Role ambiguity- Nurses' performance.}

\section{Introduction}

Nurse performance is vital to quality patient care outcomes. Role conflict and role ambiguity have a joint effect on job performance ratings. Unclear roles and responsibilities affect employee performance (Daron, 2012). Moustaka \& Constantinidis, (2010) recognized that role ambiguity and role conflict are stressful characteristics of the working role..

Role conflict occurs when an individual is subject to competing or conflicting sets of expectations and demands in the organization, or when the principle of unity of command is violated. It diminishes job satisfaction and effectiveness (Tarrant, 2008). Some common causes of role conflict are unclear expectation, poor communication, lack of clear jurisdiction, incompatibilities or disagreements based on differences on temperament or attitudes, individual or group conflict of interest, and operational of staffing changed. All of these types of role conflict can disrupt working relationships and result in lower productivity (Marquis \& Huston, 2009).

Role ambiguity refers to the perception of unclear or uncertain role expectations. The inability to perceive a clear behavioral expectation reduces the likelihood of an expectation will be acted upon, increasing the likelihood of interpersonal conflict and perceived lack of effectiveness within the organizational role. Role behavior expectations should come from a clear and unified source (Abrahamson, 2008).

Role ambiguity results from unclear expectation for one's performance. Individuals with high tolerance for ambiguity can deal better with the strain that come from uncertainties and, therefore, are likely to be able to cope with role ambiguity (Sullivan \& Decker, 2005). Sharma, (2002) explained that an employee face role ambiguity when inducted into a position or when changes are introduced in the organizational structure and processes.

Increasing role clarity, by reducing role conflict and role ambiguity, is likely to help people obtain a higher level of job performance, satisfaction, organizational commitment and a lower level of turnover intention and job tension. Too much conflict can produce undesirable results such as hostility and lack of cooperation, which lower performance (Griffin, 2002). 
Characteristics of nurses at increased risk for role conflict tend to be those who are younger in age, have fewer years in their present staff position, and work in more acute patient care areas. Nurses with high levels of interaction with others in and across work areas were found to be more likely to experience role ambiguity and role conflict than those working in roles with specific job tasks. The more clearly identifiable the role components, the less likely role ambiguity and role conflict will occur (Kleinman, 2008 \& Gormley, 2005).

Nationally, there was a study done by Ahmed, (2008) her study was titled "the role of organization climate in conflict management among nursing personnel working at Assuit University Hospitals" found that a moderate negative relationship between role conflict and job satisfaction and moderate negative relationship between role ambiguity and job satisfaction. The finding of this study concluded that intra-group conflict was the highest and interpersonal conflict was the lowest. Positive organization climate was associated with higher percentage of effective resolution and more positive impact of conflict. Another study was done by El Sayed, (1997) who found that $90 \%$ of nurses interns perceived role conflict and $85 \%$ of them perceived role ambiguity compared to $73.3 \%$ of baccalaureate nursing graduates perceived role conflict and $36.7 \%$ of them perceived role ambiguity.

\section{Significance of the study :}

It has been observed in Minia University Hospital, a lack in role delineation and absence of job description among nurses leading to role conflict and role ambiguity which may further undermine nursing care activities and lead to poor performance. So, it is important to study role conflict and role ambiguity among nurses and identify its causes from the viewpoints of nurses to moderate and control them and examine whether the role conflict and role ambiguity influence performance.

\section{Aim of the study:}

1- Identify causes of role conflict and role ambiguity at Minia University Hospital.

2- Determine level of role conflict, role ambiguity and performance at Minia University Hospital, and

3- To find out the relation among role conflict, role ambiguity and nurses' performance at Minia University Hospital.

\section{Research question:}

- To what extent nurses experience role conflict and role ambiguity with regards to demographic variables?

- Is there a relationship among role conflict, role ambiguity and nurses' performance?

\section{Subject and Methods:}

Research design:

A descriptive Correlational design was utilized in the present study.

Setting:

The study carried out at Minia University Hospital. Subjects:

The sample consists of all nurses who are working in all general and special inpatient units at Minia University Hospital with total number $(n=85)$; they are classified as the following:

\begin{tabular}{|l|l|c|}
\hline Hospital name & \multicolumn{1}{|c|}{ Unit } & \multicolumn{1}{|c|}{ Number of nurses } \\
\hline \multirow{5}{*}{$\begin{array}{c}\text { Minia University } \\
\text { Hospital }\end{array}$} & Medical dept. & 10 \\
\cline { 2 - 3 } & Ophthalmology dept. & 3 \\
\cline { 2 - 3 } & Dermatology dept. & 5 \\
\cline { 2 - 3 } & Recovery dept & 8 \\
\cline { 2 - 3 } & Medical care unit & 10 \\
\cline { 2 - 3 } & Tropical dept. & 10 \\
\cline { 2 - 3 } & Surgical dept. & 9 \\
\cline { 2 - 3 } & Urology & 4 \\
\cline { 2 - 3 } & Orthopedic dept. & 5 \\
\cline { 2 - 3 } & Neurosurgery dept. & 5 \\
\cline { 2 - 3 } & health insurance dept (1) & 4 \\
\cline { 2 - 3 } & health insurance dept. (2) & 7 \\
\cline { 2 - 3 } & ENT & 5 \\
\hline
\end{tabular}




\section{Tools of data collection:}

The study tools consisted of four tools, it includes:1. Socio-demographic characteristics sheet:

It was designed to collect socio-demographic characteristics about nurses working at units in Minia and Suzan Mubarak University Hospitals such as (age, marital status, qualification, years of experience, average number of patient you are responsible about, and kind of shifts nurses taken).

2) Role conflict and role ambiguity questionnaire: This tool is developed by El Sayed (1997), and translated by the researcher. It divided into four parts in the following sequence:

$\underline{1^{\text {st }}}$ part Perception of role conflict: It includes nine questions related to perception of role conflict among nurses. Responses with a Five point Likert Scale ranging from (strongly disagree- disagree - uncertainagree- strongly agree). The scoring system was ranging from (1 to 5), respectively that high scores indicating high role conflict.

$\underline{2^{\text {nd }}}$ part Causes of role conflict: It includes twenty two questions related to causes of role conflict with scoring system $(\mathrm{Yes}=2)$ or $(\mathrm{No}=1)$ respectively.

$\underline{\mathbf{3}^{\text {rd }}}$ part Causes of role ambiguity: It includes ten questions related to causes of role conflict with scoring system $(\mathrm{Yes}=2)$ or $(\mathrm{No}=1)$ respectively.

$\underline{4}^{\text {th }}$ part Perception of role ambiguity: It includes six questions related to perception of role ambiguity among nurses. Responses with a Five point Likert Scale ranging from (strongly disagree- disagree uncertain- agree- strongly agree). The scoring system was ranging from (5 to 1 ) respectively, high scores indicating high role ambiguity.

Role conflict total scoring system:

If the score range from (28-45) the level of role conflict will consider high; and if the score range from (19-27) the level of role conflict will consider moderate; and if range from (9-18) the level of role conflict will consider low.

Role ambiguity total scoring system

If the score range from (19-30) the level of role ambiguity will consider high; and if the score range from (13- 18) the level of role ambiguity will consider moderate; and if range from (6-12) the level of role ambiguity will consider low.

3) Observation checklist for Assessment of Nursing Performance.

This tool is developed by Jernigan \& young (1983). The tool consists of 24 items concerned with measuring the performance of the nurses. The tool is divided into the following:

- Assessment consists of (2) items.

- Planning consists of (4) items.

- Implementation consists of (12) items.

- Evaluation consists of (6) items.
Scoring system for nursing performance assessment:

The items of observation checklist is checked either (exceptional performance, above average, satisfactory, unsatisfactory), with scoring system (3, $2,1,0)$, respectively.

If overall performance score range from ( 0 to 21$)$ the performance will considered unsatisfactory, and if score range from (22 to 37$)$ the performance will considered satisfactory, and if range from (38 to 57) the performance will considered above average and if score from (58 to 72) the performance will considered exceptional performance.

\section{2- Administrative design:-}

Official approval to carry out this study was obtained from the director of Minia University Hospital and head of each department.

3- Operational design:-

Preparation phase:-

This phase started from June to September 2010 and included the following:

1- Reviewing the available literature concerning the topic of the study.

2- Preparing and translating of the study's tools.

Pilot study:-

A pilot study carried out to assess tools clarity and applicability. Moreover, to identify problems that may be encountered during the actual data collection. It applied on eleven nurses from the hospitals that included at the main subjects of the study. Data collected from the pilot study was analyzed.

\section{Reliability of tools:}

The reliability was assessed in a pilot study by measuring their internal consistency using Cronbach's alpha coefficient method. This turned to be $(\alpha=0.80)$ for perception of role conflict tool; $(\alpha=$ $0.78)$ for perception of role ambiguity tool; $(\alpha=0.80)$ for causes of role conflict tool; and $(\alpha=0.81)$ for causes of role ambiguity tool. Thus indicates a high degree of reliability for the study tools.

\section{Collection of data phase:}

The researcher met each subject in the study to explain the purpose of the study and to ask for participation. After obtaining verbal consent, the study tools handled to participated nurse manager to be filled. The data collection was done through structured interview with participants to fill the forms. This took about twenty minutes for each participant interview. The observation checklist was filled by the researcher. The observation was done during the routine work of nurses. Each nurse was observed during work three times. 
Each observation takes a shift. Observation carried out in the morning shift. The present study carried out within about four months started from October 2010 to January 2011.

4- Statistical design:

Data entry and analysis were done using SPSS version 16 (Statistical Package for Social Science).
Data were presented using descriptive statistics in the form of frequencies and percentages, mean, standard deviation, range and chi-square. Pearson correlation analysis was used for assessment of the interrelation among quantitative variable. Statistical significance was considered at $\mathrm{p}$ - value $\leq 0.05$.

\section{Results :}

Table (1): Distribution of the studied nurses according to demographic characteristics (Total No.=106).

\begin{tabular}{|c|c|c|}
\hline \multirow[t]{2}{*}{ Demographic characteristics } & \multicolumn{2}{|c|}{$\begin{array}{c}\text { Minia University Hospital } \\
\text { (No.=85) }\end{array}$} \\
\hline & No. & $\%$ \\
\hline \multicolumn{3}{|l|}{ 1. Age } \\
\hline $\begin{array}{ll}\text { - } & <25 \\
\text { - } & 25-35 \\
\text { - } & 36-45 \\
\text { - } & >45\end{array}$ & $\begin{array}{c}42 \\
28 \\
11 \\
4\end{array}$ & $\begin{array}{c}\mathbf{4 9 . 4} \\
32.9 \\
13.0 \\
4.7\end{array}$ \\
\hline \multicolumn{3}{|l|}{ 2. Sex } \\
\hline $\begin{array}{l}\text { - Male } \\
\text { - Female }\end{array}$ & $\begin{array}{l}32 \\
53\end{array}$ & $\begin{array}{l}37.6 \\
62.4\end{array}$ \\
\hline \multicolumn{3}{|l|}{ 3. Marital status } \\
\hline $\begin{array}{l}\text { - Single } \\
\text { - Married }\end{array}$ & $\begin{array}{l}36 \\
49\end{array}$ & $\begin{array}{l}42.4 \\
\mathbf{5 7 . 6}\end{array}$ \\
\hline \multicolumn{3}{|l|}{ 4. Qualifications } \\
\hline $\begin{array}{l}\text { - Technical institute } \\
\text { - Diploma }\end{array}$ & $\begin{array}{l}14 \\
71\end{array}$ & $\begin{array}{l}16.5 \\
83.5\end{array}$ \\
\hline \multicolumn{3}{|l|}{ 5. Shifts frequently taken } \\
\hline $\begin{array}{l}\text { - Morning } \\
\text { - Evening } \\
\text { - Night }\end{array}$ & $\begin{array}{l}39 \\
21 \\
25\end{array}$ & $\begin{array}{l}\mathbf{4 5 . 9} \\
24.7 \\
29.4\end{array}$ \\
\hline \multicolumn{3}{|l|}{ 6. Years of experience } \\
\hline $\begin{array}{l}\text { - }<3 \\
\text { - } 3-6 \\
\text { - } 7-10 \\
\text { - }>10\end{array}$ & $\begin{array}{l}20 \\
27 \\
10 \\
28\end{array}$ & $\begin{array}{l}23.5 \\
31.8 \\
11.8 \\
\mathbf{3 2 . 9}\end{array}$ \\
\hline
\end{tabular}

(*) statistically significant at $\leq 0.05$ 
Table (2): Distribution for causes of role conflict among nurses in Minia University Hospital (No. = 85).

\begin{tabular}{|c|c|c|c|c|}
\hline \multirow{2}{*}{ Items } & \multicolumn{2}{|c|}{ Yes } & \multicolumn{2}{|c|}{ No } \\
\hline & No. & $\%$ & No. & $\%$ \\
\hline $\begin{array}{l}\text { 1. Individual educated with professional values are in opposition } \\
\text { with bureaucratic value and expectations. }\end{array}$ & 81 & 95.3 & 4 & 4.7 \\
\hline $\begin{array}{l}\text { 2. Differing views concerning what nursing is and what it should } \\
\text { be about. }\end{array}$ & 75 & 88.2 & 10 & 11.8 \\
\hline $\begin{array}{l}\text { 3. Disagreement between medical and nursing view of what the } \\
\text { nurse's role should be. }\end{array}$ & 84 & 98.8 & 1 & 1.2 \\
\hline $\begin{array}{l}\text { 4. Perceived public expectation, self expectations and self image } \\
\text { are frequently in conflict }\end{array}$ & 73 & 85.9 & 12 & 14.1 \\
\hline $\begin{array}{l}\text { 5. Most nurses are woman; their caring work is viewed as a } \\
\text { natural attribute and not valued. }\end{array}$ & 42 & 49.4 & 43 & 50.6 \\
\hline $\begin{array}{l}\text { 6. Nurse's own personal values differ from those of the } \\
\text { profession }\end{array}$ & 33 & 38.8 & 52 & 61.2 \\
\hline $\begin{array}{l}\text { 7. Physicians ignore nurses' suggestion indicating they do not } \\
\text { want feedback. }\end{array}$ & 68 & 80.0 & 17 & 20.0 \\
\hline 8. Physicians are trained to be in authority over nurses. & 82 & 96.5 & 3 & 3.5 \\
\hline $\begin{array}{l}\text { 9. Nurses want to be more independent, have professional } \\
\text { responsibility and accountability for patient care. }\end{array}$ & 78 & 91.8 & 7 & 8.2 \\
\hline 10. Different mangers set conflicting rules. & 76 & 89.4 & 9 & 10.6 \\
\hline 11. Supervisor con not tolerate idea are different from their own. & 56 & 65.9 & 29 & 34.1 \\
\hline $\begin{array}{l}\text { 12. Doctors underestimate nurses through their perception of } \\
\text { nurses as handmaidens. }\end{array}$ & 72 & 84.7 & 13 & 15.3 \\
\hline 13. Lack of cooperation between nurses. & 56 & 65.9 & 29 & 34.1 \\
\hline 14. Shortage of staff. & 81 & 95.3 & 4 & 4.7 \\
\hline $\begin{array}{l}\text { 15. Organizations do not provide nurses with adequate } \\
\text { educational opportunities. }\end{array}$ & 85 & 100 & 0 & 0.0 \\
\hline 16. Leaving a sick child home alone in order to go to work. & 66 & 77.6 & 19 & 22.4 \\
\hline 17. Crowded space & 83 & 97.6 & 2 & 2.4 \\
\hline 18. Nurses are not prepared for change, they are threatened. & 76 & 89.4 & 9 & 10.6 \\
\hline $\begin{array}{l}\text { 19. Nurses are not recognized or respected and unable to control } \\
\text { the situation. }\end{array}$ & 41 & 48.2 & 44 & 51.8 \\
\hline 20. Personal goals conflict with organizational goals. & 69 & 81.2 & 16 & 18.8 \\
\hline 21. Incompatible perceptions or activities. & 76 & 89.4 & 9 & 10.6 \\
\hline $\begin{array}{l}\text { 22. Double lines of authority inherent in the hospital organization } \\
\text { system }\end{array}$ & 82 & 96.5 & 3 & 3.5 \\
\hline
\end{tabular}

$(*)$ statistically significant at $\leq 0.05$ 
Table (3): Distribution for the causes of role ambiguity among nurses in Minia University Hospital (No.=85).

\begin{tabular}{|c|c|c|c|c|}
\hline \multirow{2}{*}{ Items } & \multicolumn{2}{|c|}{ Yes } & \multicolumn{2}{|c|}{ No } \\
\hline & No. & $\%$ & No. & $\%$ \\
\hline 1. Lack of clear job expectations & 69 & 81.2 & 16 & 18.8 \\
\hline $\begin{array}{l}\text { 2. Hospital policy, procedure and routine are not } \\
\text { clear. }\end{array}$ & 78 & 91.8 & 7 & 8.2 \\
\hline 3. Responsibilities are not defined. & 61 & 71.8 & 24 & 28.2 \\
\hline $\begin{array}{l}\text { 4. Lack of orientation to the facilities and equipment } \\
\text { in the unit. }\end{array}$ & 33 & 38.8 & 52 & 61.2 \\
\hline $\begin{array}{l}\text { 5. Period of adjustment is not adequate to new } \\
\text { responsibilities. }\end{array}$ & 66 & 77.6 & 19 & 22.4 \\
\hline 6. Job duties and work objectives are not clear. & 59 & 69.4 & 26 & 30.6 \\
\hline $\begin{array}{l}\text { 7. Nurse's perception of her role is different from the } \\
\text { actual situation. }\end{array}$ & 73 & 85.9 & 12 & 14.1 \\
\hline $\begin{array}{l}\text { 8. Nurse in a role is uncertain about the role } \\
\text { expectations of one or more members of the role } \\
\text { set. }\end{array}$ & 71 & 83.5 & 14 & 16.5 \\
\hline $\begin{array}{l}\text { 9. Lack of information about duties, authority or } \\
\text { criteria of performance evaluation }\end{array}$ & 72 & 84.7 & 13 & 15.3 \\
\hline
\end{tabular}

$(*)$ statistically significant at $\leq 0.05$

Table (4): Levels of role conflict and role ambiguity among nurses in Minia University Hospital (total no. $=85$ ).

\begin{tabular}{|c|c|c|c|c|c|c|c|c|c|}
\hline \multirow[t]{2}{*}{$\begin{array}{l}\text { Levels of } \\
\text { role conflict }\end{array}$} & \multicolumn{2}{|c|}{$\begin{array}{c}\text { Minia } \\
\text { University } \\
\text { Hospital } \\
(\text { No.= 85) } \\
\end{array}$} & \multirow[t]{2}{*}{$X^{2}$} & \multirow[t]{2}{*}{$P$ - value } & \multirow[t]{2}{*}{$\begin{array}{l}\text { Levels of } \\
\text { role } \\
\text { ambiguity }\end{array}$} & \multicolumn{2}{|c|}{$\begin{array}{c}\text { Minia } \\
\text { University } \\
\text { Hospital } \\
\text { (No.= 85) } \\
\end{array}$} & \multirow[t]{2}{*}{$X^{2}$} & \multirow[t]{2}{*}{$\begin{array}{c}P- \\
\text { value }\end{array}$} \\
\hline & No & $\%$ & & & & No & $\%$ & & \\
\hline $\begin{array}{ll}\text { - } & \text { High } \\
\text { - } & \text { Moderate } \\
\text { - } & \text { Low }\end{array}$ & $\begin{array}{c}82 \\
3 \\
0\end{array}$ & $\begin{array}{c}96.5 \\
3.5 \\
0.0\end{array}$ & \multirow[t]{2}{*}{74.42} & \multirow[t]{2}{*}{$\begin{array}{l}\text { - High } \\
\text { - } \text { Moderate } \\
\text { - }\end{array}$} & $\begin{array}{ll}\text { - } & \text { High } \\
\text { - } & \text { Moderate } \\
\text { Low }\end{array}$ & $\begin{array}{l}44 \\
29 \\
12\end{array}$ & $\begin{array}{l}51.8 \\
34.1 \\
14.1\end{array}$ & \multirow[t]{2}{*}{18.09} & \multirow[t]{2}{*}{$0.000 *$} \\
\hline Total & 85 & 100 & & & Total & 85 & 100 & & \\
\hline
\end{tabular}


Table (5): Relation between demographic characteristics and role conflict levels among studied nurses in Minia University Hospital (No. = 85)

\begin{tabular}{|c|c|c|c|c|c|c|}
\hline \multirow{3}{*}{$\begin{array}{l}\text { Demographic } \\
\text { characteristics }\end{array}$} & \multicolumn{4}{|c|}{ Role conflict levels } & \multirow{3}{*}{$\mathbf{X}^{2}$} & \multirow{3}{*}{$\mathbf{P}$-value } \\
\hline & \multicolumn{2}{|c|}{ High } & \multicolumn{2}{|c|}{ Moderate } & & \\
\hline & No. & $\%$ & No. & $\%$ & & \\
\hline \multicolumn{7}{|l|}{ 1. Age } \\
\hline $\begin{array}{l}\text { - }<25 \\
\text { - } 25-35 \\
\text { - } 36-45 \\
\text { - }>45\end{array}$ & $\begin{array}{c}41 \\
27 \\
11 \\
3\end{array}$ & \begin{tabular}{c|}
$\mathbf{4 8 . 2}$ \\
$\mathbf{3 1 . 8}$ \\
12.9 \\
3.5
\end{tabular} & $\begin{array}{l}1 \\
1 \\
0 \\
1\end{array}$ & $\begin{array}{l}1.2 \\
1.2 \\
0.0 \\
1.2\end{array}$ & 5.981 & 0.113 \\
\hline \multicolumn{7}{|l|}{ 2. Sex } \\
\hline $\begin{array}{l}\text { - Male } \\
\text { - Female }\end{array}$ & $\begin{array}{l}30 \\
52\end{array}$ & $\begin{array}{l}35.3 \\
61.1\end{array}$ & $\begin{array}{l}2 \\
1\end{array}$ & $\begin{array}{l}2.4 \\
1.2\end{array}$ & 1.116 & 0.291 \\
\hline \multicolumn{7}{|l|}{ 3. Marital status } \\
\hline $\begin{array}{l}\text { - Single } \\
\text { - Married }\end{array}$ & $\begin{array}{l}35 \\
47\end{array}$ & $\begin{array}{l}41.1 \\
\mathbf{5 5 . 3}\end{array}$ & $\begin{array}{l}1 \\
2\end{array}$ & $\begin{array}{l}1.2 \\
2.4\end{array}$ & 0.104 & 0.748 \\
\hline \multicolumn{7}{|l|}{ 4. Qualifications } \\
\hline $\begin{array}{l}\text { - Technical institute } \\
\text { - Diploma }\end{array}$ & $\begin{array}{l}13 \\
69\end{array}$ & $\begin{array}{l}15.3 \\
\mathbf{8 1 . 1}\end{array}$ & $\begin{array}{l}1 \\
2\end{array}$ & $\begin{array}{l}1.2 \\
2.4\end{array}$ & 0.643 & 0.423 \\
\hline \multicolumn{7}{|l|}{ 5. Shifts } \\
\hline $\begin{array}{l}\text { - Morning } \\
\text { - Evening } \\
\text { - Night }\end{array}$ & $\begin{array}{l}38 \\
20 \\
24\end{array}$ & $\begin{array}{l}44.7 \\
23.5 \\
28.2\end{array}$ & $\begin{array}{l}1 \\
1 \\
1\end{array}$ & $\begin{array}{l}1.2 \\
1.2 \\
1.2\end{array}$ & 0.217 & 0.897 \\
\hline \multicolumn{7}{|l|}{ 6. Years of experience } \\
\hline $\begin{array}{ll}- & <3 \\
\text { - } & 3-6 \\
\text { - } & 7-10 \\
\text { - } & >10\end{array}$ & $\begin{array}{l}19 \\
27 \\
10 \\
26\end{array}$ & $\begin{array}{l}22.4 \\
\mathbf{3 1 . 7} \\
11.8 \\
\mathbf{3 0 . 5}\end{array}$ & $\begin{array}{l}1 \\
0 \\
0 \\
2\end{array}$ & $\begin{array}{l}1.2 \\
0.0 \\
0.0 \\
2.4\end{array}$ & 2.554 & 0.466 \\
\hline
\end{tabular}


Table (6): Relation between demographic characteristics and role ambiguity levels among studied nurses in Minia University Hospital (No.= 85)

\begin{tabular}{|c|c|c|c|c|c|c|c|c|}
\hline \multirow{3}{*}{$\begin{array}{l}\text { Demographic } \\
\text { characteristics }\end{array}$} & \multicolumn{6}{|c|}{ Role ambiguity levels } & \multirow{3}{*}{$\mathbf{X}^{2}$} & \multirow{3}{*}{$\begin{array}{c}\text { P- } \\
\text { value }\end{array}$} \\
\hline & \multicolumn{2}{|c|}{ High } & \multicolumn{2}{|c|}{ Moderate } & \multicolumn{2}{|c|}{ Low } & & \\
\hline & No & $\%$ & No & $\%$ & No & $\%$ & & \\
\hline \multicolumn{9}{|l|}{ 1. Age } \\
\hline $\begin{array}{ll}\text { - } & <25 \\
\text { - } & 25-35 \\
\text { - } & 36-45 \\
\text { - } & >45\end{array}$ & $\begin{array}{c}23 \\
17 \\
4 \\
0\end{array}$ & $\begin{array}{c}27.1 \\
20.0 \\
4.7 \\
0.0\end{array}$ & $\begin{array}{c}16 \\
8 \\
4 \\
1\end{array}$ & $\begin{array}{c}18.9 \\
9.4 \\
4.7 \\
1.2\end{array}$ & $\begin{array}{l}3 \\
3 \\
3 \\
3\end{array}$ & $\begin{array}{l}3.5 \\
3.5 \\
3.5 \\
3.5\end{array}$ & 17.169 & 0.009* \\
\hline \multicolumn{9}{|l|}{ 2. Sex } \\
\hline $\begin{array}{l}\text { - Male } \\
\text { - Female }\end{array}$ & $\begin{array}{l}17 \\
27\end{array}$ & $\begin{array}{l}20.0 \\
31.8\end{array}$ & $\begin{array}{c}7 \\
22\end{array}$ & $\begin{array}{c}8.2 \\
25.9\end{array}$ & $\begin{array}{l}8 \\
4\end{array}$ & $\begin{array}{l}9.4 \\
4.7\end{array}$ & 6.578 & 0.037* \\
\hline \multicolumn{9}{|l|}{ 3. Marital status } \\
\hline $\begin{array}{l}\text { - Single } \\
\text { - Married }\end{array}$ & $\begin{array}{l}21 \\
23\end{array}$ & $\begin{array}{l}24.7 \\
27.1\end{array}$ & $\begin{array}{l}14 \\
15\end{array}$ & $\begin{array}{l}16.5 \\
17.6\end{array}$ & $\begin{array}{c}1 \\
11\end{array}$ & $\begin{array}{c}1.2 \\
12.9\end{array}$ & 6.625 & $0.036 *$ \\
\hline \multicolumn{9}{|l|}{ 4. Qualifications } \\
\hline $\begin{array}{l}\text { - Technical institute } \\
\text { - Diploma }\end{array}$ & $\begin{array}{c}6 \\
38\end{array}$ & $\begin{array}{c}7.1 \\
44.7\end{array}$ & $\begin{array}{c}7 \\
22\end{array}$ & $\begin{array}{c}8.2 \\
25.9\end{array}$ & $\begin{array}{c}1 \\
11\end{array}$ & $\begin{array}{c}1.2 \\
12.9\end{array}$ & 2.074 & 0.355 \\
\hline \multicolumn{9}{|l|}{ 5. Shifts } \\
\hline $\begin{array}{l}\text { - Morning } \\
\text { - Evening } \\
\text { - Night }\end{array}$ & $\begin{array}{c}20 \\
9 \\
15\end{array}$ & $\begin{array}{l}\mathbf{2 3 . 5} \\
10.6 \\
17.7\end{array}$ & $\begin{array}{l}14 \\
8 \\
7\end{array}$ & $\begin{array}{c}16.5 \\
9.4 \\
8.2\end{array}$ & $\begin{array}{l}5 \\
4 \\
3\end{array}$ & $\begin{array}{l}5.9 \\
4.7 \\
3.5\end{array}$ & 1.546 & 0.818 \\
\hline \multicolumn{9}{|l|}{ 6. Years of experience } \\
\hline $\begin{array}{l}\text { - }<3 \\
\text { - } 3-6 \\
\text { - } 7-10 \\
\text { - }>10\end{array}$ & $\begin{array}{c}9 \\
19 \\
7 \\
9\end{array}$ & $\begin{array}{c}10.6 \\
22.4 \\
8.2 \\
10.6\end{array}$ & $\begin{array}{c}10 \\
6 \\
1 \\
12\end{array}$ & $\begin{array}{c}11.7 \\
7.1 \\
1.2 \\
14.1\end{array}$ & $\begin{array}{l}1 \\
2 \\
2 \\
7\end{array}$ & $\begin{array}{l}1.2 \\
2.4 \\
2.4 \\
8.2\end{array}$ & 14.270 & 0.027* \\
\hline
\end{tabular}

$(*)$ statistically significant at $\leq 0.05$

Table (7): Correlation matrix of study variables (performance, role conflict, role ambiguity) in Minia University Hospital (No. $=85$ )

\begin{tabular}{|l|c|c|c|c|c|c|}
\hline \multirow{2}{*}{ Variables } & \multicolumn{2}{|c|}{ Performance score } & \multicolumn{2}{c|}{ Role conflict score } & \multicolumn{2}{c|}{ Role ambiguity score } \\
\cline { 2 - 7 } & r & P & r & P & r & P \\
\hline Performance score & & & -0.183 & 0.094 & -0.119 & 0.279 \\
\hline Role conflict score & -0.183 & 0.094 & & & 0.50 & $0.0000^{*}$ \\
\hline Role ambiguity score & -0.119 & 0.279 & 0.50 & $0.0000^{*}$ & & \\
\hline
\end{tabular}

(*) Statistically significant at $\leq 0.05$ 
Table (8): Factors that contribute the nurses' performance in Minia University Hospital (No. =85).

\begin{tabular}{|l|c|c|}
\hline \multicolumn{1}{|c|}{ Factor } & Standardized Coefficients & \multirow{2}{*}{ p- value } \\
\cline { 2 - 2 } & Beta & 0.110 \\
\hline Years of experience & -0.244 & 0.029 \\
\hline Age & -0.237 & 0.084 \\
\hline Role ambiguity & -0.195 & 0.243 \\
\hline Marital status & -0.172 & 0.111 \\
\hline Role conflict & -0.171 & 0.249 \\
\hline Sex & -0.133 & 0.686 \\
\hline Qualification & -0.047 & 0.712 \\
\hline Most shifts nurses taken & 0.044 & \\
\hline
\end{tabular}

Table (1): Illustrates that about half of the study sample were working in Minia University Hospital, aged less than 25 years $(49.4 \%)$ and less than two third of study sample were female $(62.4 \%)$, and more than half of study sample were married $(57.6 \%)$ and the majority of study sample graduated from diploma nursing $(83.5 \%)$, and $(45.9 \%)$ of study sample taken morning shift more frequently and about one third of study sample had more than 10 years of experience $(32.9 \%)$.

Table (2): Demonstrates that all study sample mentioned that organizations do not provide nurses with adequate educational opportunities are a cause of role conflict (100\%). The majority of the study sample mentioned seven items about causes of role conflict in the following sequences (disagreement between medical and nursing view of what the nurse's role should be; crowded space; physicians are trained to be in authority over nurses; double lines of authority inherent in the hospital organization system; individual educated with professional values are in opposition with bureaucratic value and expectations; shortage of staff; and nurses want to be more independent; have professional responsibility and accountability for patient care) with $(98.8 \%, 97.6 \%$, $96.5 \%, 96.5 \%, 95.3 \%, 95.3 \%$ \& $91.8 \%$ ) respectively. Less than half of the study sample mentioned that most nurses are women; their caring work is viewed as a natural attribute and not valued, and nurses are not recognized or respected and unable to control the situation are causes of role conflict $(49.4 \%$ \& $48.2 \%)$ respectively and more than one third mentioned that nurse's own personal values which differ from those of the profession is a cause of role conflict $(38.8 \%)$.

Table (3): displays that the majority of the study sample mentioned causes of role ambiguity in the following sequence; hospital policy, procedure and routine are not clear; nurse's perception of her role is different from the actual situation; lack of information about duties, authority or criteria of performance evaluation; nurse in a role is uncertain about the role expectations of one or more members of the role set; lack of clear job expectations; period of adjustment is not adequate to new responsibilities; responsibilities are not defined and job duties and work objectives are not clear with $(91.8 \%, 85.9 \%$, $84.7 \%, 83.5 \%, 81.2 \%, 77.6 \%, 71.8 \& 69.4 \%$ ) respectively. The lowest percentage cause was lack of orientation to the facilities and equipment in the unit $(38.8 \%)$.

Table (4): Shows that role conflict was perceived as high by $96.5 \%$ of study sample who working in Minia University Hospital .while only $3.5 \%$ of study them have moderate level of role conflict and no one of study sample have low level of role conflict. There was a statistically significant difference between levels of role conflict $(\mathrm{p}=0.000)$. While, more than the half of the study sample who working in Mina University Hospital has high level of role ambiguity $(51.8 \%)$ and more than one third of them have moderate level of role ambiguity (34.1\%). While, only $14.1 \%$ of them have low level of role ambiguity. There was a statistically significant difference between levels of role ambiguity $(\mathrm{p}=0.000$ ).

Table (5): Illustrates that about half of study sample have high level of role conflict aged less than 25 years $(48.2 \%)$ and less than of one third of study sample have high level of role conflict aged from 2535 years $(31.8 \%)$. As regard to sex, less than two third of study sample were female and have high level of role conflict (61.1\%) comparing to more than one third in male category (35.3\%). As regard to marital status, more than half of study sample have high level of role conflict and were married $(55.3 \%)$ and $(81.2 \%)$ of studied sample have high level of role conflict and have diploma degree. Less than half of study sample have high level of role conflict and take morning shift more frequently (44.7\%). Less than one third of study sample has high level of role conflict and has experience from 3-6 years and more than 10 
years $(31.7 \% \& 30.5 \%)$ respectively. There were no statistically significant differences between age groups, sex, marital status, qualification, shifts most frequently taken and years of experience as regard to distribution of role conflict levels.

Table (6): Illustrates that $(27.1 \%)$ of study sample have high level of role ambiguity aged less than 25 years. And less than one third of study sample have high level of role ambiguity were female $(31.8 \%)$ comparing to $(20 \%)$ of study sample have high level of role ambiguity were male. As regard to marital status, $(27.1 \%)$ of study sample has high level of role ambiguity were married comparing to $(24.7 \%)$ of study sample have high level of role ambiguity were single. As regard to qualification, less than half of study sample have high level of role ambiguity, have diploma degree $(44.7 \%)$ and $(23.5 \%)$ of study sample were have high level of role ambiguity and take frequently morning shift. As regard to years of experience, $(22.4 \%)$ of study sample have high level of role ambiguity have years of experience from 3-6 years. There was statistically significant difference as regard to age groups, sex, martial status, years of experience $(\mathrm{P}=0.009,0.037,0.036,0.027)$ respectively.

Table (7): Shows that performance has negative correlation with role conflict $(r=-0.183 \& p=0.094)$ and with role ambiguity $(\mathrm{r}=-0.119 \& \mathrm{p}=0.279)$. There is a positive correlation between role ambiguity with a highly statistically significant difference with role conflict $(\mathrm{r}=0.5 \& \mathrm{p}=0.0000)$.

Table (8): Illustrates that number of years of experiences, age and role ambiguity level were the highest contributing factors to low performance. On the other hand, kind of shifts that nurses frequently taken and qualification were the lowest contributing factors for low performance.

\section{Discussion:}

Most managers and organizations are looking for ways to drive improved performance of individuals. We often look at systems, personnel characteristics, talent, knowledge, etc. Those are all good places to check. However, we often fail to examine the role itself and how it is structured and how clear the role is defined (Evand, 2010).

Several researchers have been studying factors influencing performance in health organizations with emphasis on worker factors and work environment factors (Al-Ahmadi, 2009).

In current study, about half of study sample aged less than 25 years (table, 1). This result might be attributed to a lot of nurses in the last years in Minia University Hospital changing their career by completing another study to be appointed in other departments inside their hospital. Other nurses choose traveling abroad because of unsuitable working condition and inadequate salaries.

These results are in accordance with (McNutt, 2008) who mentioned that if a nurse is not happy in a certain hospital or community because of compensation and management, she will look for a place that will provide her with the benefits she deserves. Personal issues can also cause a nurse to quit. This can include the issues she faces with her family. Nurses work on shifts like most serviceoriented industries. Their schedule is a challenge to manage.

In the present study, less than two third of study subjects who working in Minia University Hospital were females. This results might be attributed to that majority of nurses who graduated from secondary diploma school and clinical institute were female (table, 1). This is supported by Walling, (2011) who mentioned that while the proportion of men entering the nursing profession has been growing, it remains a female-dominated occupation.

All study sample mentioned that organizations do not provide nurses with adequate educational opportunities is a cause of role conflict (table, 2) this consistent with (Declan, 2009) who stated that nursing is a scientifically rigorous discipline, which requires the updated information on a regular basis to ensure best possible care is provided to patients. To ensure nurses are properly updated most hospitals and medical agencies must offer regular training and seminars.

In present study nurses mention that shortage of staff is a cause of role conflict (table, 2). This is supported by the American College of Chest Physicians, (2000) which reported that there is a crisis in quality critical care services due to insufficient numbers of qualified doctors and nurses. The World Health Organization, (2003) commented concern on an increasing flow and active recruitment of nurses from developing countries to industrialized countries when the developing countries themselves have insufficient numbers to meet their own workforce requirements.

In current study majority of studied sample mentioned that there is disagreement between medical and nursing view of what the nurse's role should be is a cause of role conflict (table, 2). This might by attributed to doctors frequently underestimate nursing role this consistent with (Cockburn et al., 2008) who mentioned that nurses are seen as handmaidens and helpmeets to doctors rather than as scientific professionals in their own right, who often practice with a surprising degree of autonomy. 
In current study majority of studied sample mentioned that different mangers set conflicting rules; and double lines of authority inherent in the hospital organization system were perceived as causes of role conflict by the nurses (table, 2). This consistent with (Tarrant, 2008) who mentioned that single line of authority allows for effective control and coordination of resources and personnel.

In current study majority of studied sample mentioned that differing views concerning what nursing is and what it should be about; perceived public expectation, self expectations and self image are frequently in conflict are perceived as a cause of role conflict (table, 2$)$. This consistent with $(\mathbf{W u} \&$ Norman, 2006) who mentioned that role conflict among nurses because nurses are often "trained" to manage different expectations from competing groups. Nurse often has to balance different expectations. Consider the clinical site where nursing faculty have one set of expectations for performance, staff nurses often have a different set of expectations and patients and physicians may also have varying expectations of skill levels and knowledge from the nurse.

In present study majority of studied sample mentioned that crowded space is a cause of role conflict (table, 2). This result consistent with (Swansburg \& Swansburg, 2002) who mentioned that when the nurses work in crowded spaces they must constantly interact with other staff member, visitors and physician. This is particularly true in crowded units. Such condition cause stress that lead leads to burnout and high turnover rates.

In the current study studied sample mention the following as causes of role ambiguity (hospital policy, procedure and routine are not clear; nurse's perception of her role different from the actual situation; lack of information about duties, authority or criteria of performance evaluation; nurse in a role is uncertain about the role expectations of one or more members of the role set and period of adjustment is not adequate to new responsibilities; responsibilities are not defined) (table, 3 ).

This result supported by (Kruger et al., 2008) who mentioned that role ambiguity occurs when individuals feel uncertain about their work, and arises from factors such as the size and complexity of modern organization, the rapid rate of change, restrictions on the flow of information, uncertainty on the part of worker about his / her authority, the application of rules and regulations and vague goals. Role ambiguity lead to poor work performance. Richter, (2011) added that role ambiguity is lack of clarity on one's job profile. The employee remains confused about his or her role or tasks, caused by lack of required information, and lack of communication of available information.

Lack of clear job expectations; Job duties and work objective are not clear and nurse in a role is uncertain about the role expectations of one or more members of the role set (table, 3). This result consistent with (Kleinman, 2008) who stated that role clarity and feedback regarding job performance expectations and the understanding of reciprocal role expectations of nursing and non-nursing work group members are very important. Sharing job descriptions across disciplines may be an effective strategy that will allow staff to articulate expectations for themselves and others in specific patient care situations.

"Lack of orientation to the facilities and equipment in the unit" is a cause of role ambiguity in the current study (table, 3).this consistent with (Greenwood, 2000) who attributed that formal unit orientation programs facilitate the transition of new graduates. Edwards et al., 2000) added that role ambiguity may ensue from lack of orientation in one's scope of responsibilities

In the present study, role conflict was perceived as high by majority of studied sample who working in Minia University Hospital. While about half of studied nurses who working in Minia University Hospital have high level of role ambiguity (table, 4). This is consistent with (El Sayed, 1997) who demonstrated that $73.3 \%$ of baccalaureate nursing graduates perceived role conflict and $36.7 \%$ of them perceived role ambiguity.

In the present study, about half of study sample have high level of role conflict aged less than 25 years and less than one third of study sample have high level of role conflict and have years of experience from 3-6 (table, 5). This results is supported by (Kleinman, 2008) who mentioned that nurses at increased risk for role conflict tend to be those who are younger in age, have fewer years in their present staff position.

The result in the present study revealed that there is no relation between age and educational levels as regard distribution of role conflict (table, 5). This is inconsistent with Poduval, (1999) who mentioned that there is a significant negative relationship is obtained between role conflict with age and educational levels

Less than two third of study subject were female and have high level of role conflict. This is supported by (Evandrou et al. 2002) who mentioned that women assuming multiple roles results in work family conflict because time and energy are shared, clubbed and even extended across the two spheres of activity. 
There is no statistically significant difference between sex and role conflict (table, 5). This consistent with (Macionis, 2006) who mentioned that there is no significant difference between male and female in the experienced role conflict.

More than half of study sample have high level of role conflict and were married (table, 5). This result is in accordance with (Abdul\& Roshan 2010) who stated that there are contradictory role expectations from working women while she is at work and at home. On professional front she is expected to be committed, dynamic, competitive, straight forward, and non-sentimental and act in a "business like" manner and at home, she is expected to be sweet, soft, sensitive, adaptable, gentle, unassertive and domesticated. As an ideal woman wants to fulfill the duties of a faithful wife, a sacrificing mother, obedient and respectful daughter in-law and an efficient and highly placed career woman. These contradictory expectations cause the most confusion, tension and create many other problems for her. A woman employee finds it difficult to do justice to the two roles at the same time. An attempt to play one of the roles with perfection leads to an inadvertent sacrifice of the other.

In the current study marital status did not show a significant relation with role conflict (table, 5). This was inconsistent with (Nair \& Gaither, 1999) who stated that role conflict arises due to multiple commitments to different domains of an individual's life.

Less than half of study sample have high level of role conflict during morning shift more frequently (table, 5). This might be attributed to increase workload in the morning shifts and all routine procedures occur at the morning shift. This was consistent with Natvig et al., (2007) who mentioned that increasing job demands were a problem for nurses. It could have consequences for patient safety in relation to inadequate time to properly test equipment and insufficient time for the preparation of medications. In addition, daily control routines in the morning could not be completed.

In the current study, there is statistically significant difference between age groups as regard to distribution of role ambiguity (table, 6). This might be attributed that the younger nurses have lower information about their duties and responsibilities, this supported by (Keerthy, 2008) who mentioned that because they are new in the field; receiving vague or insufficient information; not having much experience, they are not able to plan their job. Employees tend to be satisfied with their jobs when roles are clearly defined.
According to the study findings, there is significant relation between role ambiguity and sex where female has higher level of role ambiguity (table, 6). This may be attributed to the multiple roles of female nurses so they unable to have clear information about their roles and this are inconsistent with (Poduval, 1999) who mentioned that there is no significant difference in the role ambiguity experienced by male and female.

In the current study, marital status show a significant relation with role ambiguity where married nurses have high level of role ambiguity than single nurses (table, 6). This might be attributes to multiple roles of married nurses which lead to confusion and this was inconsistent with (Wolverton \& Gmelch 2002) who stated that role ambiguity did not vary by marital status.

According to the study finding, there were no statistically significant differences between educational level and distribution of role conflict (table, 6). This might be attributed to the presence of accurate, definite clear job description for each nurses category in both hospitals. This was inconsistent with (Poduval, 1999) who mentioned that there is a significant negative relationship between role ambiguity and educational level.

In the present study, studied nurses who having from 3- 6 years of experience have high level of role ambiguity than other and there was significant relation between role ambiguity and experience (table, 6). This is supported by (Chang \& Daly, 2001) who mentioned that new graduates often experience overload as a result of the difficulties they experience prioritizing tasks and time management. Such overload can compound role ambiguity; and this result was consistent with (Sakires et al., 2009) who stated that more years of experience reflecting greater role clarity.

According to the study findings, there is positive correlation and statistically significant difference between role ambiguity and role conflict (table, 7). This is consistent with (Tarrant, 2008) who found that role conflict was positively correlated with role ambiguity. This is inconsistent with the finding of (Ibrahim \& Gamal, 2010) who mentioned that there was negative correlation and highly statistical significant difference between role ambiguity and role conflict.

In the current study, role ambiguity has negative correlation with performance and one of the most contributing factors for low performance (table, 7). This result is consistent with (Tubre \& Collins, 2000) who concluded in their meta- analysis that role ambiguity is negatively related to performance. Ortqvist and Wincent, (2006) mentioned that role ambiguity was correlated with performance tension. 
During periods of organizational change in that expectations and roles vary; employees are likely to feel helpless since they must incorporate new information in order to successfully perform their role.

This result supported by (Evand, 2010) who mentioned that role ambiguity (or lack of role clarity) has been shown to have a significant negative impact on performance because individuals are uncertain about key aspects of their job, and therefore, they are unable to perform at their highest level.

In the current study, performance has a negative correlation with role conflict (table, 7). This result is in-accordance with (Nutshell, 2011) who mentioned that employees encountering role conflict may experience psychological withdrawal from the job leading to reduced job performance.

In the current study, result show that marital status is one of the most contributing factors to low performance (table, 8). This result is in-accordance with (Hong et al., 1995) who mentioned that Single employees perceive more employee benefit impact on job performance than married ones. Single employees perceive more impact of social and self-actualization benefit on performance than married ones. Single employees put emphasis on further education/training and career development, life attendance flexible working time, while married workers perceive more importance of day-care, dividends, child education subsidies and pensions.

In the current study result show that years of experience is one of the most contributing factors to low performance (table, 8). This result might be attributed to new graduating nurses are more obligated to work and have new knowledge and hospital do not provide staff development program. So, knowledge and skills of nurses who have many years of experience are out of date which affect negatively on nurses' performance. This results are inconsistent to (Al-Ahmadi, 2009) who mentioned that years of experience were found to be strong predictors of job performance, indicating that work experience influences performance.

\section{Conclusions:}

In the light of the study results, the following conclusions can be drawn:-

1. Majority of studied sample at Minia University Hospital have high level of role conflict regardless of demographic characteristics.

2. About half of studied sample have high level of role ambiguity.

3. Age differ significantly in regard to distribution of level of role ambiguity.
4. Performance has negative correlation with role conflict and role ambiguity.

5. Role conflict has a positive correlation with role ambiguity.

\section{Recommendations:}

On the light of the results of this study the following recommendations will be suggested:

1. Nurses in administration position should plan an orientation program to orient nurses about hospital policy, rules, regulation, job description and responsibilities, other's expectation, facilities and equipment, performance evaluation standard.

2. Developing a performance appraisal tool to evaluate nursing staff performance with different educational classification.

3. Policy regarding nursing license in Egypt must be modified and nurses must passes practical and theoretical exam every three years to renew and maintain license, this enforce nurses to improve their knowledge and skills frequently and protect patients from nurses who have a bad performance.

\section{References:}

1. Abdul. G\& Roshan. A (2010): Conflicting

worlds of working women: findings of an exploratory study, Indian Journal of Industrial Relations, Volume: 46 Source Issue: 1, available

2. Abrahamson, Peter (2008) 'European Union influence on Central American Integration: The case of the coming Association Agreement'. Paper presented in the ISA RC, $19^{\text {th }}$ Annual Conference: The Future of Social Citizenship: Politics, Institutions and Outcomes, Stockolm, 4-6 September.

3. Ahmed. A (2008) : The role of organization climate in conflict management among nursing personnel working at Assuit University Hospitals, Master thesis, Faculty of Nursing, and Assuit University, Unpublished master degree thesis.

4.Al-Ahmadi. H (2009): Factors affecting performance of hospital nurses in Riyadh Region, Saudi Arabia, Institute of Public Administration, Riyadh, Saudi Arabia, International Journal of Health Care, Quality Assurance, Vol. 22 No. 1, pp. 40-54

American College of chest Physicians (2000): International Conference, San Francisco, CA October 2000. Published in Chest 200118(Suppl. 4).

5. Chang E, Daly J. (2001): Managing the transition from student to graduate nurse. Transitions in Nursing: Preparing for Professional Practice, Sydney, Maclennan and Petty,; pp 1-14. 
6. Cockburn, B ; Reed, L \& Cash, R (2008): Head nurse available @ @ http://headnurse.blogspot.com/2008/08/handmaidenshelpmeets-and-problem-of.html.

7. Daron. R, 2012: Ombuds Works as a Neutral Party to Keep the Peace Across UCSF,http://www.ucsf.edu/news/2012/02/11473/o mbuds-works-neutral-party-keep-peace-acrossucsf.

8. Declan. T, (2009): Importance of Continuing Nursing Education available @ http://www.uaseducation.com/articles/666/1/Import ance-of-Continuing-Nscoursing-

Education/Page1.htm

9. Edwards, D; Burnard , P ; Coyle, D ; Fothergill, A \& Hannigan, B (2000): Stress and burnout in community mental health nursing: a review of the literature. Journal of Psychiatric Mental Health Nursing, volume 7 , issue 1, and Pp. 7-14.

10. El Sayed. K (1997): Relationship between perceived role conflict and role ambiguity with stress level among new Baccalaureate nursing student and in tern in Tanta University. Unpublished master degree thesis.

11. Evand. W (2010): Role ambiguity and performance, master of business administration, Taylor University, available @ http://taylormba.org/2010/07/06/role-ambiguityperformance/

12. Evandrou Maria, Karen Glaser \& Ursula Henz (2002): "Multiple Role Occupancy in Midlife: Balancing Work and Family Life in Britain ", The Gerontologist. Volume 42, issue 6, pp 78-189

13. Gormley. K, (2005): Organizational climate, role ambiguity, role conflict and nurse faculty work role balance. Division of Research and Advanced Studies of the University of Cincinnati published thesis of doctoral of philosophy (Ph.D.), the College of Nursing.

14.Greenwood J. (2000): Critique of the graduate nurse: an international perspective. Nurse Education today 2000; 20: 17-23.

15. Griffin. W (2002): Management, Houghton Mifflin, $7^{\text {th }}$ ed, New York pp. 592, 600.

16. Hong. J, Yang. S, Wang. L, FuChiou. E, Sun. F and Huang. T (1995): Impact of employee benefits on work motivation and productivity the Department of Industrial Education, National Taiwan Normal University, Taipei, Taiwan, The International Journal of Career Management, Volume 7, issue 6, pp. 10-14.

17. Jernigan , D and Young, A (1983): standards job descriptions and performance evaluations for nursing practice, Appleton - century- crofts/ Norwalk, Connecticut.
18. Ibrahim. M \& Gamal. A ( 2010): Relationship between Perceived Role Ambiguity and Role Conflict with Quality of Nurses' Performance Working In Maternity Units at Selected Hospitals, published thesis, Umm Al-Qura University available@ http://uqu.edu.sa/page/ar/131545

19. Keerthy. N, (2008): Assessment the difference between high and low criterion groups of emotional intelligence with regard to occupational stress avaiavle @ http://thebigbees.com/discussions.aspx

20. Kleinman. C, (2008): Role Conflict and the Nurse, Part I, (http://www.w3c.org/TR/1999/REChtml401-19991224/loose.dtd").

21. Kruger, E ; Smit , W \& Ie Roux , P (2008): Basic Psychology for Human Resource Practitioners , Creda Communication , $9^{\text {th }} \mathrm{ed,} \mathrm{ch}$ 10, P.196.

22. Macionis, J (2006): Society Basics Person Prentice Hall. New Jersey, $8^{\text {th }}$ ed.

23. Marquis .L \& Huston. J (2009): leadership roles and management functions in nursing, Lippincott William \& Wilkins, $6^{\text {th }} \mathrm{Ed}$, $C h$ $24^{\text {th }}$ pp.569: 592

24. McNutt. B (2008): What Causes Nurses to Quit? Available @ http://ezinearticles.com/?WhatCauses-Nurses-to-Quit?\&id=1416683

25. Moustaka. E \& Constantinidis, T (2010): Sources and effects of Work-related stress in nursing, Health Science Journal, Volume 4, Issue 4, pp. 210:216

26. Nair.K \&Gaither. C (1999) Effects of Work, Non Work, and Role Conflict on the Overall Life Satisfaction of Pharmacy Faculty, College of Pharmacy, University of Michigan, 428 Church Street Ann Arbor, Ml 48109-1065, American Journal of Pharmaceutical Education, Volume 63.

27. Natvig. G, Gundersen. D, Berland. A (2007): Patient safety and job-related stress: A focus group study, Department of Nursing Education, Stord/Haugesund University College, Bjørnsonsgate 45, Haugesund 5528, Norway, Haugesund Hospital, Helse Fonna, Norway, jpurnal of Intensive and Critical Care Nursing Volume 24, Issue 2, April 2008, pp. 90-97

28. Nutshell . H, (2011): Role Stress, Role Conflict and Role Ambiguity in Retail Available @ http://www.hrnutshell.com/topics/topicscovered-group1-key-to-survival/human-resourcemanagement/item/181-role-stress-role-conflictand-role-ambiguity

29. Ortqvist . D, Wincent. J (2006): Prominent consequences of role stress,: A meta- analytic review, international journal of stress management, volume 13, issue 4, pp. 399: 422. 
30. Poduval. P (1999): Gender differences in work stress of executives. Management Studies gVol. 37 (2-3), 109-113

31. Richter. N (2011): Role Ambiguity and Role Conflict in Job Satisfaction available @ http://www.brighthub.com/office/humanresources/articles/102263.aspx

32. Sakires. J, Doherty. A, Misener. K (2009): Role Ambiguity in Voluntary Sport Organizations, Journal of Sport Management Volume: 23, Issue 5, Pages, pp.615643

33. Sharma. R. 2002. Executive burnout: Contribution of role related factors. Indian Journal of Industrial Research, volume38, issue1, pp. 8195.

34. Sullivan and Decker (2005): Effective Management in nursing, Canada. Addison Wesley Longman $2^{\text {nd }}$ edition

35. Swansburge, $R$ and Swansburge , $R$ (2002): Introduction to management and leadership for nurse managers, Jones \& Bartlett publisher, USA, $3^{\text {rd }}$ ed, ch 23 , P. 506.

36. Tarrant. A (2008): Role conflict, role ambiguity and job satisfaction of the nurse executive, Published doctoral dissertation, School of Nursing , Division of Health Sciences, University of Nevada, Las Vegas December 2008

37. The American College of Chest Physicians, (2000): International Conference, San Francisco, CA October 2000. Published in Chest 200118 ( Suppl 4).

38. The World Health Organization, (2003): The World Health Report 2003- nursing and midwifery workforce management, India

39. Tubre, T. C. and Collins, J. M (2000): A Meta-Analysis of the Relationships between Role Ambiguity, Role Conflict, and Job Performance, Journal of Management (2000) pp. 155-169.

40. Walling. P (2011): How did Nursing Become a Female Profession available @ http://www.themale-nurse.com/2011/06/how-did-nursing-becomefemale.html

41. Wolverton. M \&Gmelch. W (2002): College Deans: leading from within, USA, American Council on Education and The Oxyr Press, $1{ }^{\text {st }}$ Ed, 50:55.

42. Wu and Norman, I (2006): An investigation of job satisfaction, organizational commitment and role conflict and role ambiguity in a sample of Chinese undergraduate nursing students. Journal of Nurse Education Today, volume 26, issue 4, Pp. 304-314. 